\title{
THE EFFECTS OF DELAYS IN ROAD CONSTRUCTION PROJECTS IN TRIPOLI, LIBYA
}

\author{
Aboubaker. Y.Y. Alfakhri ${ }^{1}$, Amiruddin Ismail ${ }^{1}$, Muhamad Azry Khoiry ${ }^{1 *}$ \\ ${ }^{1}$ Civil Engineering Programme, Smart and Sustainable City Research Centre, \\ Faculty of Engineering \& Built Environment, Universiti Kebangsaan Malaysia, 43600 Bangi, \\ Selangor, Malaysia
}

(Received: January 2017 / Revised: September 2017 / Accepted: July 2018)

\begin{abstract}
Construction delays have become endemic in Libya. It is imperative to create awareness of the extent to which such delays can adversely affect project delivery, especially with regard to road construction projects. It is clear that the Libyan road construction industry also faces the issue of not being able to complete projects within the allocated time. This paper identifies the effects of road construction delays, evaluates these through a questionnaire, and assesses them using an empirical method. A detailed review of related literature produced the secondary data, while the primary data was obtained via a structured questionnaire which targeted the road construction projects owners, consultants and contractors. A $71 \%$ response rate was achieved; 256 out of the 360 questionnaires sent out were returned. Descriptive statistics were used to analyze the data received from the questionnaires. The findings of the study reveal that the major outcomes of road construction project schedule overruns in Tripoli, Libya include cost overruns, time extensions, disputes, loss of profit, breaches of contract, poor quality of work and company's bad reputation. The study makes a contribution to the knowledge of the subject of the outcomes of road construction project schedule overruns in Tripoli. Computation of the means and standard deviations, together with a structural equation model, have been used for the data analysis and inference. It is found that delays in road construction projects widely lead to cost overrun, time overrun, litigation and disputes. The findings of the study also provide significant insights into the construction industry, which will help it formulate strategies in order to avoid delays and their consequences. The most important effects identified were time overrun, cost overrun and obstruction of economic and country development. The recommendations and limitations are discussed in the concluding part of the study.
\end{abstract}

Keywords: Construction delay; Effects; Libya; Road projects; Tripoli

\section{INTRODUCTION}

The construction industry plays an important role in establishing the infrastructure required for socio-economic development, besides directly contributing to economic growth (Firmawan et al., 2012). Usually, the success of a project is measured based on time, quality and the amount of work completed within a specific budget. Thus, it is necessary to manage cost and schedule overruns when undertaking construction projects. Completion of construction projects by means of the overall effective usage of cost and time will result in cost savings for the country and therefore contribute to economic development (Aibinu \& Jagboro, 2002). The factors which

\footnotetext{
*Corresponding author's email: azrykhoiry@ukm.edu.my, Tel. +603-89216200, Fax.+603-89118344 Permalink/DOI: https://doi.org/10.14716/ijtech.v9i4.2219
} 
cause delays in construction projects also have an effect on the overall effective usage of cost and time will result in cost savings for the country and therefore contribute to economic development (Aibinu \& Jagboro, 2002). The factors which cause delays in construction projects also have an effect on the overall project (Rahsid et al., 2013). Time overrun, cost overrun, total abandonment, disputes and arbitration are the main effects of project delays in the construction industry in Libya (Kusakc1 et al., 2017). As the country struggles to recover from the conflict of 2011 with two different governing powers, international oil companies are partially resuming operations in the country. However, the Libyan oil industry has to face new challenges, such as security issues, a deregulated market, a vulnerable legal framework and lack of a central governing power. In such a business environment, an effective project management framework is of paramount importance for a quick recovery. Such a framework will help to avoid delays in projects and identify the factors which cause these, and their possible consequences (Kusakc1 et al., 2017). Hence, the aim of this paper is to identify the outcomes of construction delays in road projects in Tripoli, Libya.

Infrastructure development plays a vital role in improving the overall development and progress of any country. However, delays in construction projects have negative impacts, such as time and cost overrun, litigation and abandonment of the project. The most adverse impact is that it gives a bad impression to foreign investors, which ultimately leads to a downturn in national development. According to Sweis et al. (2008), delays often occur due to poor project management related to project owners, contractors and consultants. In addition, general conditions including weather, the law and order situation, and deteriorating economic conditions will cause delays in the completion of projects. Hence, there is a dire need to measure the effect of such delays on construction projects in Tripoli. In order to fill the literature gap and address the problems of the construction industry in Libya, this study aims to measure the effects of delays, such as time overrun, cost overrun, litigation and project abandonment, on construction projects.

\section{EFFECTS OF DELAYS RELATED TO CONSTRUCTION}

The effects of delays are a result of factors which are not identified and resolved. Numerous factors can result in cost and time overruns in various types of projects, and client satisfaction will decrease if the cost of a project or schedule exceeds the planned budget (Kaliba et al., 2009). The outcomes of construction project schedule overruns have been identified as follows:

- Time overrun: A project experiences schedule overrun if the stipulated completion time is exceeded. Schedule overrun implies late delivery or completion based on the specified time that has been agreed by all the parties involved in the construction project (Sunjka \& Jacob, 2013).

- Cost overrun: Critical factors in road construction projects in Jordan are delay and cost overrun. Other factors that contribute to construction cost and schedule overruns in public work projects should be identified, as recommended by Al-Hazim and Salem (2015).

- Dispute and claims: The losses incurred due to schedule overruns result in disputes and claims (Sunjka \& Jacob, 2013). The six main factors which caused delays in Iranian construction projects were identified by Pourrostam and Ismail (2012) as cost overrun, time overrun, total abandonment, disputes, litigation and arbitration.

- Arbitration: Project delays can lead to arbitration between contractual parties. Some of the parties might not accept the mediator's decision and will appeal in an arbitration process. The decision to address the issue will also be made by the arbitrator. Projects will incur extra costs and time following the engagement of professional arbitrators (Sunjka \& Jacob, 2013). 
These findings support the studies conducted by Honrao and Desai (2015) and Hasan et al. (2014). However, a total of eight outcomes of schedule overruns were identified by Sunjka and Jacob (2013), namely: (a) budget overrun, a project is said to face a budget overrun if it is completed at a cost that is higher than that budgetted; (b) time overrun, a project is said to encounter time overrun if the stipulated completion time is exceeded; (c) bad public relations, consultants, contractors and clients risk their public reputation if projects are delayed; (d) poor project quality, issues related to project quality may arise if there is inferior workmanship and/or use of inferior quality materials; (e) arbitration, a project may incur additional cost and time following the engagement of professional arbitrators; (f) litigation, courts may be used to resolve disputes, especially when severe penalties are at stake; (g) total abandonment, unresolved issues that result in delays in the execution of a project can lead to total abandonment; and (h) disputes and claims, these are the result of losses incurred due to delays by either party in the contract.

\section{RESEARCH METHODOLOGY}

According to Yang and Peng (2008), a pilot study can be used to correct any fault found in a questionnaire before conducting the main research. In this work, such a study was conducted by distributing the structured questionnaire to selected contractors, consultants and owners involved in road construction projects in Libya. The respondents were asked to indicate the level of relevance of the causative factors and the level of the effect factors on a five-point Likert scale, as well as to verify whether the factors assigned to the group were accurate, based on the actual scenarios in the construction industry. A total of 53 respondents working in the Libyan road construction industry participated in the pilot survey. 46 questionnaires were returned, amongst which 31 were valid, thereby yielding a 58\% usable response rate. According to Fellows (1997), the usable response rate usually ranges from $25 \%$ to $35 \%$. Therefore, the response rate obtained in the pilot study meets the requirements for running preliminary analysis. Both primary and secondary information sources were used. The primary data was collected through the survey method, while the secondary was obtained from a careful review of archival records and from the literature. Specifically, the primary data was collected via a structured questionnaire survey. This survey was distributed to 360 construction professionals, who included consultants, contractors and owners at present involved in road construction work in Tripoli.

These numbers were considered to be significant for the survey in order to obtain a true reflection of the outcomes of road construction project schedule overruns. There was a $71 \%$ response rate to the 360 questionnaires distributed, with 256 being returned, this was considered sufficient for the analysis according to Moser and Kalton (1973). If the return rate is less than $30-40 \%$, the survey results may be deemed biased and of little value. The frequency distributions and percentages of all the respondents were utilized for the data presentation and analysis. In an attempt to identify the outcomes of road construction projects in Tripoli, a fivepoint Likert scale was utilized. According to Sekaran (2003), the Likert scale is an interval scale that specifically uses five anchors, namely Strongly Disagree, Disagree, Neutral, Agree and Strongly Agree.

From the literature review, a total of ten well-recognised effects of delay related to road construction were identified. In order to rank these, the identified effects of delay were included in a questionnaire. The main objective of the survey was to determine the level of importance of all the effects of delay on road construction projects, as each has a different level of impact on the delay of a project, according to its nature and complexity. This part of the questionnaire was an attempt to identify the effects of construction delay from three dimensions, namely Finance, 
Site and Government. The item codes, as well as their descriptions related to the effects of construction delay, are shown in Table 1.

Table 1 Item code and description of the effects of construction delay

\begin{tabular}{|c|c|c|}
\hline No & Item Code & Item Description \\
\hline \multicolumn{3}{|r|}{ Effects related to Finance $(E F)$} \\
\hline 1 & EF1 & Time overrun \\
\hline 2 & EF2 & Cost overrun \\
\hline 3 & EF3 & Poor quality \\
\hline \multicolumn{3}{|r|}{ Effects related to Government (EG) } \\
\hline 4 & EG1 & Disputes \\
\hline 5 & EG2 & Arbitration \\
\hline 6 & EG3 & Breach of contract \\
\hline 7 & EG4 & Litigation \\
\hline \multicolumn{3}{|r|}{ Effects related to Site $(E S)$} \\
\hline 8 & ES1 & Delays in other projects related to the main project \\
\hline 9 & ES2 & Disruption of traffic movement \\
\hline 10 & ES3 & Obstruction of economic and country development \\
\hline
\end{tabular}

The analysis method was the first phase of the data analysis (which mainly included statistical analysis) and was conducted after screening the data using SPSS 21.0 for Windows. Data screening is an essential part of any analysis process, in which the presence of outliers, as well as the normality, reliability and validity of the data, are assessed. This phase also involved Exploratory Factor Analysis (EFA) and assessment of the correlations between the scales. The second phase of the data analysis involved Confirmatory Factor Analysis (CFA), which aimed to examine the effects of delay on road construction projects and to study the relationship between these effects.

\section{FINDING AND DISCUSSION}

\subsection{Analysis data}

Descriptive Analysis: Table 2 shows the results of the 256 usable questionnaires. Project Owners were the largest respondent group, at 110 (42.96\%); consultants the second largest, with 77 respondents $(30.07 \%)$; and the smallest group of respondents was that of contractors, at $69(26.95 \%)$. Table 2 also shows the findings related to the type of organization in which the respondents worked, with 103 in the public sector, 65 in the private sector, and 88 working in both the public and private sectors.

Table 2 Questionnaires distributed, type of organization and years of experience

\begin{tabular}{|c|c|c|c|c|c|}
\hline Questionnaires & Contractors & Owners & Consultants & & Total \\
\hline Distributed & 96 & 146 & 118 & & 360 \\
\hline Respondents & 69 & 110 & 77 & & 256 \\
\hline Percentage & $26.95 \%$ & $42.96 \%$ & $30.07 \%$ & & $71 \%$ \\
\hline \multicolumn{6}{|c|}{ Type of organization } \\
\hline Public & Private & Both & & Total & \\
\hline 103 & 65 & 88 & & 256 & \\
\hline $40.23 \%$ & $25.39 \%$ & $34.37 \%$ & & $100 \%$ & \\
\hline \multicolumn{6}{|c|}{ Years of experience } \\
\hline Years & $<5$ years & $5-10$ years & $11-15$ years & $>15$ years & Total \\
\hline Respondents & 35 & 78 & 68 & 75 & 256 \\
\hline Percentage & $13.67 \%$ & $30.46 \%$ & $26.56 \%$ & $29.29 \%$ & $100 \%$ \\
\hline
\end{tabular}


Fortunately, the largest proportion of professionals who participated in the survey had more than 15 years' experience in road construction projects, which reflects well on the reliability of the data collected. 75 respondents $(29.29 \%)$ had more than 15 years' experience, and 68 $(26.56 \%)$ had between 11 and 15 years. Of the remaining respondents, $78(30.46 \%)$ had between 5 and 10 years' experience, while 35 (13.67\%) had less than 5 years' experience (see Table 2).

Table 3 shows the value of the projects and the party responsible for delays. The results reveal that $39.10 \%$ (100 respondents) were working on small-sized construction projects (under 5 million Libyan Dinar (LD)), 25.00\% (64 respondents) on medium-sized projects (5-15 million LD), $12.90 \%$ (33 respondents) on large-size projects (16-30 million LD), and $23.00 \%$ (59 respondents) were working on very large construction projects (over 30 million LD). This shows that the size of the project has a direct relationship with the level of impact due to delay factors; smaller-sized projects have more impact compared to larger-sized ones.

Table 3 also shows the results with regard to the parties responsible for delays in road construction projects, with contractors, at 127 (49.60\%), being the largest group. Owners were the second largest group, at $92(35.9 \%)$, while consultants emerged as the party with the least responsible for delays, with 27 respondents $(10.5 \%)$.

Table 3 Value of project and party responsible for delays

\begin{tabular}{lccccc}
\hline & \multicolumn{2}{c}{ Value of Project (Libyan Dinar) } & Total \\
\hline Value & over 30 mil. & $16-30$ million & $5-15$ million & under 5 mil. \\
Respondents & 59 & 33 & 64 & 100 & 256 \\
Percentage & $23.00 \%$ & $12.90 \%$ & $25.00 \%$ & $39.10 \%$ & $100 \%$ \\
\hline \multicolumn{7}{c}{ Party } & responsible for delays & & \\
\hline Responsible for delay & Contractors & Owners & Consultants & Other & Total \\
Respondents & 127 & 92 & 27 & 10 & 256 \\
Percentage & $49.6 \%$ & $35.9 \%$ & $10.5 \%$ & $3.9 \%$ & $100 \%$ \\
\hline
\end{tabular}

Following the mean item score of the factors, they were then ranked in descending order, from the highest to the lowest. A project that is subject to delay will have exceeded the specified period, which means that time is wasted that could have been utilized in other profit-generating projects. Since time is money, the delay also causes cost overrun. The contractor will need to pay more for labour, machinery and overheads. Moreover, the owner's monetary resources will be tied up with the delayed project, and traffic movement will be disrupted by the closing of the main roads for development and construction. Additionally, roads provide links that connect road users with other areas, which may include recreational and investment projects. So a delay in a road project may also lead to a delay in any investment projects that depend on the roads. Table 4 shows descriptive statistics of the delay effects. All the item values were greater than 3.00, which proves that the respondents scored the 256 items on a scale higher than "undecided", and even to some extent agreed.

The findings highlighted in Table 4 show that time overrun has the highest ranking, with a mean index score value of 4.10. An increase in the final cost of a project is ranked second, with a mean index score of 3.82, while with a mean index score of 3.57 , delays in other projects related to the main project are ranked third. Time is essential in every phase of life. Whenever a contract is written and a date is specified, time periods will be impacted by the outcomes of delay. All the other factors are affected by time since more monetary resources must be employed if there is an increase in final cost. Poor quality and obstruction of economic and urban development as a result of incomplete projects are scored with mean values of 3.50 and 3.47, respectively. Disputes, disruption of traffic movement, breach of contract, litigation and 
arbitration have low rankings, with mean values of 3.36, 3.32, 3.21, 3.18 and 3.16 respectively. These five factors are closely linked. Litigation and arbitration may be the result of disputes between the parties involved. In relation to this, if a decision by the arbitration panel is not accepted by any of the parties involved, this may lead to a serious legal contest, which will hamper work progress.

Reliability: In this section, the Cronbach's alpha value of the overall model was much higher than $0.7(\mathrm{a}=0.890)$, as proven by the results of the SPSS analysis. Such a value suggests that all the items are reliable, so the test is internally consistent (Ho, 2006). However, none of the items was shown to increase reliability if deleted, as indicated by "Cronbach's Alpha if Item Deleted". Therefore, it can be concluded that all 10 items in relation to the effects of construction delay can be retained. At this stage it is also necessary to conduct a separate reliability analysis for all the subscales of the effects of construction delay; Cronbach's alpha test for the items is shown in Table 4.

Table 4 Descriptive statistics and Cronbach's alpha of delay effects

\begin{tabular}{ccccc}
\hline Item & N Statistic & Mean & Std. Deviation & Cronbach's Alpha \\
\hline EF1 & 256 & 4.10 & .897 & .859 \\
EF2 & 256 & 3.82 & .983 & .850 \\
ES3 & 256 & 3.57 & 1.149 & .847 \\
EF3 & 256 & 3.50 & .925 & .784 \\
ES1 & 256 & 3.32 & 1.099 & .791 \\
EG1 & 256 & 3.36 & 1.043 & .848 \\
ES2 & 256 & 3.47 & 1.101 & .903 \\
EG3 & 256 & 3.21 & 1.093 & .852 \\
EG4 & 256 & 3.18 & .942 & .788 \\
EG2 & 256 & 3.16 & .931 & .856 \\
\hline
\end{tabular}

Exploratory Factor Analysis (EFA): As mentioned previously, EFA is conducted in order to obtain acceptable constructs and validity at the preliminary level, as well as to ascertain that only the variables which have attained high loadings are utilized in the following section. To this end, all the 10 variables of the effects of construction delay were tested using the KaiserMeyer-Olkin (KMO) measure of sampling adequacy, alongside Bartlett's test of sphericity. As observed, the KMO measure of the results is 0.872 , proving the existence of strong partial correlations throughout the study data. To confirm this, the criterion proposed by Hair et al. (2006) is considered, which states that the KMO must exceed 0.50. In addition, Bartlett's test of sphericity result is 0.000 . Because Hair et al. (2006) state that a significant level is p of less than 0.05 , it can be concluded that the obtained result is very significant. Such a small value connotes the existence of sufficient correlations between the variables of construction delay causes. The cut-off threshold is set at 0.5 , so all the components of the effects are above 0.6 , indicating that the delay effects extracted are extremely influential in contributing to road project delay to examine the number of factors extracted and to assess their suitability for conducting CFA. The results of the EFA are shown in Table 5.

Component One (Government-Related Effects): Component 1 in Table 5 is labelled as 'effects related to government'. Amongst all the effects included in this component, arbitration obtained the highest factor loading of 0.872. Delay-related effects can result in disputes that need to be settled through an arbitration process.

Component Two (Finance-Related Effects): Three effects, namely time overrun, cost overrun and poor quality, were classified under component 2. As shown in Table 5, amongst these effects, time overrun received the highest factor loading of 0.830 . Therefore, this is the most important effect of project delays. 
Table 5 Exploratory factor analysis of delay effects

\begin{tabular}{|c|c|c|c|c|}
\hline \multirow{2}{*}{ Factors Analysis } & \multirow{2}{*}{ Rotated Component Matrix } & \multicolumn{3}{|c|}{ Component } \\
\hline & & 1 & 2 & 3 \\
\hline \multirow{4}{*}{$\begin{array}{l}\text { Effects related to } \\
\text { Government (EG) }\end{array}$} & Litigation (EG3) & .880 & & \\
\hline & Arbitration (EG2) & .872 & & \\
\hline & Breach of contract (EG4) & .802 & & \\
\hline & Disputes (EG1) & .726 & & \\
\hline \multirow{3}{*}{$\begin{array}{l}\text { Effects related } \\
\text { to Finance }(\mathrm{EF})\end{array}$} & Time overrun (EF1) & & .830 & \\
\hline & Cost overrun (EF2) & & .803 & \\
\hline & Poor quality (EF3) & & .794 & \\
\hline \multirow{3}{*}{$\begin{array}{l}\text { Effects related to Site } \\
\text { (ES) }\end{array}$} & Disruption of traffic movement (ES3) & & & .843 \\
\hline & Obstruction of economic and country development (ES2) & & & .836 \\
\hline & Delay in other projects related to the main one (ES1) & & & .778 \\
\hline
\end{tabular}

Component Three (Site-Related Effects): As shown in Table 5, amongst the site-related effects, disruption of traffic received the highest factor loading of 0.843 . Even if a project is not expected to cause significant traffic congestion, the Roads and Bridges Department of the Ministry of Transportation requires project managers to develop a traffic control plan.

\subsection{Measurement Model}

Confirmatory Factor Analysis (CFA) of Delay Effects: The effects of delay were submitted for CFA immediately after conducting the EFA process. In view of the findings presented in Table 6 , the data set was analyzed. This measurement model was also hypothesized to encompass three factors: the "Effects related to Finance", the "Effects related to Site" and the "Effects related to Government". It is established through Figure 1 that based on the AMOS output this model is an acceptable fit, as its indices fulfil the requirements of a model fit. The CFA model of effects with 10 items fit indices and the modified measurement model are shown in Table 6 .

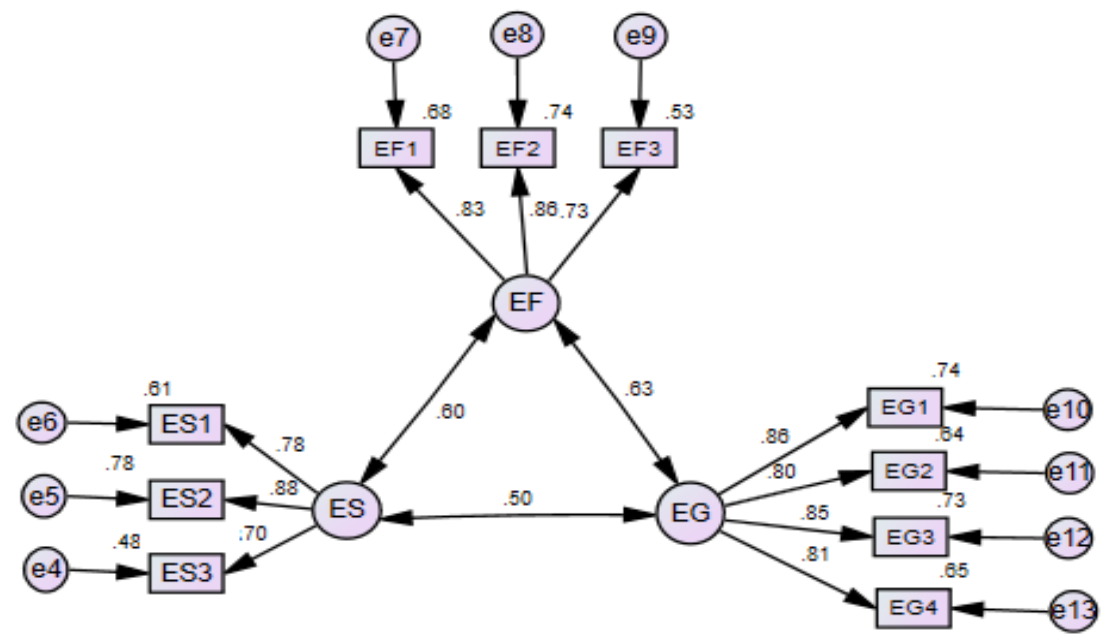

Figure 1 CFA measurement model for delay effects

The Goodness of Fit (GOF) results shows that the Chisq/df $>3$ is of an acceptable level. The GFI was 0.937, which exceeds the cut-off value of 0.8 . Therefore, the obtained GFI was deemed satisfactory. Meanwhile, the Adjusted GFI (AGFI) was equal to 0.892, which was also above the 0.8000 cut-off value. The CFI, TLI and IFI, with values exceeding the 0.9 cut-off value, all highlight the good fit of the model. The RMSEA was 0.077, which was within the acceptable fit range. 
Table 6 GOF indices of the measurement model

\begin{tabular}{lccl}
\hline \multicolumn{1}{c}{ Fit index } & Modified Model & Recommended & \multicolumn{1}{c}{ Source } \\
\hline Chisq/df & $79.887 / 32=2.49$ & $<3$ & Kline (1998) \\
P-value & 0.000 & $<0.05$ & Ullman (2001) \\
GFI & 0.937 & $>0.80$ & Hoyle (1995) \\
AGFI & 0.892 & $>0.80$ & Chau and Hu (2001) \\
CFI & 0.967 & $>0.90$ & Bagozzi and Yi (1988) \\
TLI & 0.954 & $>0.90$ & Hair et al. (2006); Ho (2006) \\
IFI & 0.967 & $>0.90$ & Hair et al. (2006); Ho (2006) \\
RMSEA & 0.077 & $<0.08$ & Schumacker and Lomax (2010) \\
\hline
\end{tabular}

\section{CONCLUSION}

The objective of the study was to measure the effects of road project delays. This has been achieved successfully, as the study found that delays in road construction projects widely lead to cost overrun, time overrun, litigation and disruption to traffic movement, which is all highly unfavourable for construction firms. The study provides significant insights into construction firms, from which they can formulate strategies to address delays and their effects on road construction projects. Moreover, cost overrun, time overrun, litigation, disputes and disruption to traffic movement are the indirect outcomes of causes of delay to road construction projects, as discussed above. On agreement of projects, it is recommended that firms should decide how to deal with delaying factors in order to address the issues of extra cost and time, courts cases and disruption to traffic movement. To overcome these negative consequences, construction firms should pay significant consideration to the causes of delay in road construction projects. By addressing these delay factors, they can avoid the extra cost and ensure their profitability. Moreover, firms should avoid court cases, and attempt to solve problems as soon as they arise. Different parties experience distinct outcomes of delay. Loss of money, time and capacity are the general outcomes. Some form of collaboration should be established between consultants, contractors and owners in the management of projects to avoid delays and reduce the effect of outcomes.

\section{ACKNOWLEDGEMENT}

The authors are grateful to the Smart and Sustainable City Research Centre, Faculty of Engineering \& Built Environment, Universiti Kebangsaan Malaysia (UKM) for FRGS/1/2017/SS03/UKM/03/1 grants to support this research and for providing research facilities.

\section{REFERENCES}

Aibinu, A., Jagboro, G., 2002. The Effects of Construction Delays on Project Delivery in Nigerian Construction Industry. International Journal of Project Management, Volume 20(8), pp. 593-599

Al-Hazim, N., Salem, Z.A., 2015. Delay and Cost Overrun in Road Construction Projects in Jordan. International Journal of Engineering \& Technology, Volume 4(2), pp. 288-293

Bagozzi, R.P., Yi, Y., 1988. On the Evaluation of Structural Equation Models. Journal of the Academy of Marketing Science, Volume 16(1), pp. 74-94

Chau, P.Y., Hu, P.J.H., 2001. Information Technology Acceptance by Individual Professionals: A Model Comparison Approach. Decision sciences, Volume 32(4), pp. 699-719

Fellows, R.F., Liu, A., 1997. Research Methods for Construction. Wiley-Blackwell

Firmawan, F. Othman, F., Yahya, K., 2012. Improving Project Performance and Waste Reduction in Construction Projects: A Case Study of a Government Institutional Building Project. International Journal of Technology, Volume 3(2), pp. 182-192 
Hair, J.F., Black, B., Babin, B., Anderson, R., Tatham, R., 2006. Multivariate Data Analysis, 6. Bask1. Upper Saddle River, NJ: Pearson Prentice Hall

Hasan, R., Suliman, S.M., Malki, Y., 2014. An Investigation into the Delays in Road Projects in Bahrain. International Journal of Research in Engineering and Science, Volume 2(2), pp. $38-47$

Ho, R., 2006. Handbook of Univariate and Multivariate Data Analysis and Interpretation with Spss. CRC Press

Honrao, M.Y., Desai, D., 2015. Study of Delay in Execution of Infrastructure ProjectsHighway Construction. International Journal of Scientific and Research Publications, Volume 5(6), pp. 1-8

Hoyle, R.H., 1995., Structural Equation Modeling: Concepts, Issues, and Applications. Sage.

Kaliba, C., Muya, M., Mumba, K., 2009. Cost Escalation and Schedule Delays in Road Construction Projects in Zambia. International Journal of Project Management, Volume 27(5), pp. 522-531

Kline, R.B., 1998. Structural Models with Observed Variables and Path Analysis: I. Fundamentals, Recursive Models. Principles and Practice of Structural Equation Modeling, pp. 95-154

Kusakc1, A.O., Ayvaz, B., Bejtagic, E., 2017. An Analysis of Causes and Effects of Delays in Construction Projects in Libyan Oil Industry. Karaelmas Fen ve Mühendislik Dergisi, Volume 7(1), pp. 274-282

Moser, C., Kalton, G., 1973. Survey Methods in Social Investigation Heinemann Educational Books, London

Pourrostam, T., Ismail, A., 2012. Causes and Effects of Delay in Iranian Construction Projects. International Journal of Engineering and Technology, Volume 4(5), pp. 598-601

Rahsid, Y., Haq, S., Aslam, M., 2013. Causes of Delay in Construction Projects of PunjabPakistan: An Empirical Study. Journal of Basic and Applied Scientific Research, Volume 3(10), pp. 87-96

Sekaran, U., 2003. Research Methods for Business: A Skill-Building Approach. New York: John Wiley and Sons

Schumacker, R.E., Lomax, R.G., 2010. A Beginner's Guide to Structural Equation Modeling. Psychology Press

Sunjka, B.P., Jacob, U., 2013. Significant Causes and Effects of Project Delays in the Niger Delta Region, Nigeria. In: Proceedings, SAIIE25, Stellenbosch, pp. 641-654

Sweis, G., Sweis, R., Hammad, A.A., Shboul, A., 2008. Delays in Construction Projects: The Case of Jordan. International Journal of Project Management, Volume 26(6), pp. 665-674

Ullman, S., 2001. Using Multivariate Statistics Bg Tabachnick, \& Ls Fidell (Eds.), pp. 653-771 Ed., P. 966, Needham Heights, MA: Allyn and Bacon

Yang, J.-B., Peng, S.-C., 2008. Development of a Customer Satisfaction Evaluation Model for Construction Project Management. Building and Environment, Volume 43(4), pp. 458-468 